\title{
Peregrinação, memória e movimento: uma análise descritiva e reflexiva sobre a função da romaria da terra
}

\section{Resumo}

\author{
Julio Cezar Adam*
}

Ninguém volta de uma peregrinação da mesma maneira que foi. Este artigo pretende descrever e analisar a $15^{\text {a }}$. Romaria da Terra do Paraná. Os relatos são feitos a partir da observação participante, descrição de filmagens, recursos do evento e de dados do relatório final da pesquisa. O objetivo do artigo é entender o que estas peregrinações, como eventos litúrgico-políticos, causam nas pessoas que delas participam. Pretendese aqui abordar dois aspectos que causam transformações: a caminhada e a memória, como formas de resistência e de transformação pessoal e coletiva. Na primeira parte do artigo, faz-se uma descrição detalhada da referida romaria e na segunda e terceira partes analisa-se a sua relação com a memória e a caminhada.

Palavras-chave: Peregrinação; Romaria da Terra; Memória; Movimento; Liturgia

\section{Pilgrimage, memory and movement: a descriptive and reflective analysis on the role of the romaria da terra}

\section{Abstract}

No one returns from a pilgrimage in the same way that it was. This article intends to describe and analyze the 15th. Pilgrimage of the Land of Paraná. The reports are made through participant observation, description of filming, event resources, and data from the final report of the survey. The purpose of the article is to understand what pilgrimages as a liturgical-political event cause in the people who participate in it. It is intended here to address two aspects that cause transformations: walking and memory, as forms of resistance and personal and collective transformation. In the first part of the article a detailed description of the mentioned pilgrimage is made and in the second and third parts its relation with the memory and the walk is analyzed.

Keywords: Pilgrimage; Pilgrimage of the Earth; Memory; Movement; Liturgy

* Teólogo pela Escola Superior de Teologia - EST, Doutor em teologia pela Universidade de Hamburgo, Alemanha e professo adjunto de Teologia Prática na Faculdades EST (São Leopoldo/RS).Email: julioadam@est.edu.br 


\section{Peregrinación, memoria y movimiento: un análisis descriptivo y reflexiva sobre la función de la romaria de la tierra}

\section{Resumen}

Nadie vuelve de una peregrinación de la misma manera que fue. Este artículo pretende describir y analizar la $15^{a}$. Romería de la Tierra de Paraná. Los relatos se realizan a través de la observación participante, descripción de imágenes, recursos del evento y datos del informe final de la investigación. El objetivo del artículo es entender lo que peregrinaciones como evento litúrgico-político causan en las personas que participan de ella. Se pretende aquí abordar dos aspectos que causan transformaciones: el caminar y la memoria, como formas de resistencia y transformación personal y colectiva. En la primera parte del artículo se hace una descripción detallada de dicha romería y en la segunda y tercera partes se analiza la relación con la memoria y la caminata.

Palabras clave: Peregrinación; Romería de la Tierra; memoria; movimiento; liturgia

\section{Introdução}

A peregrinação me encontrou antes de eu me encontrar nela e através dela. No ano de 1998 minha igreja me enviou para a Universidade de Hamburgo para realizar meu doutorado, sob a orientação do Peter Cornehl. Imbuído pela Teologia da Libertação, fui para a Alemanha com um pré-projeto cujo o objetivo era analisar a relação entre liturgia e política. Minha pergunta principal era pelo papel do culto na alienação e na libertação das comunidades e das pessoas que dele participavam. Meu professor estava de acordo com o tema, mas exigiu que eu encontrasse um caso concreto, onde a relação fosse possível de ser analisada. Iniciei uma verdadeira peregrinação na busca de um caso. Foi então que, com a preciosa ajuda de Walter Marschner, cheguei às Romarias da Terra, evento que eu conhecia apenas dos textos e de relatos.

A Romaria da Terra surgiu nos anos da ditadura brasileira (1964-1985), na região sul do Brasil, diretamente ligada à - até aquela data ainda recente - Teologia da Libertação como um movimento de protesto, dirigido contra a injustiça e violência social no campo. O apoio aos pobres da terra, índios, trabalhadores rurais, arrendatários, posseiros, pequenos agricultores, sem-terras e dos atingidos por barragens e usinas marcou o nascimento da Romaria. Desde seu início, ela foi uma mistura de elementos das peregrinações religiosas tradicionais católicas e das marchas políticas de protesto (ADAM, 2012, p. 23ss.).

Já na sua fase inicial, a Comissão Pastoral da Terra (CPT), da Igreja Católica, responsabilizou-se pelas futuras Romarias da Terra (CPT, 1997). A CPT surgiu como serviço da Igreja e encontrava-se direcionada para a organização da resistência dos trabalhadores rurais e arrendatários expulsos de suas terras. Ela 
oferece assessoria e formação pastoral, teológica, metodológica, jurídica, política e sociológica aos movimentos sociais no campo. Desde o princípio, as CPTs locais entenderam seu trabalho ecumenicamente, incluindo outras igrejas, outras comunidades religiosas e organizações não eclesiais. $\mathrm{O}$ trabalho prático da CPT tem sido realizado, sobretudo, por leigos (agentes de pastoral), mesmo que a pastoral seja cunhada, em grande medida, pelo apoio eclesiástico e pela assessoria teológica, levados a efeito por sacerdotes, pastores e pastoras.

A estrutura litúrgica das Romarias da Terra é muito semelhante em todo o Brasil. No exemplo das romarias do Paraná, de forma genérica, pode-se subdividi-las em três grandes etapas ou fases litúrgicas: 1. Chegada e abertura (saudação e abertura, saudação à mãe terra, recebimento do símbolo da Romaria, procissão com a Bíblia, procissão com a cruz da Romaria, memória); 2. O caminho de peregrinação propriamente dito, ou a procissão (com estações para protesto, música/cânticos, discursos e oração); 3. A festa de encerramento ao final do caminho (festa, ação, bênção e envio). Todo o desenrolar litúrgico encontra-se aqui nas mãos de não teólogos, não liturgos: ele é concebido, organizado, preparado, dirigido e avaliado por equipes, compostas por colaboradores leigos da pastoral, alguns teólogos e pelos próprios participantes.

Como nas Romarias tradicionais e nas procissões, também as Romarias da Terra atraem um grande número de pessoas, motivadas pelo trabalho da CPT: grupos de sem-terras (STÉDILE, 1997), organizações de pequenos agricultores (arrendatários, trabalhadores rurais, envolvidos com a agricultura familiar ou outras organizações de agricultores, sindicatos rurais); povos indígenas, comunidades de base rurais, grupos de negros e de mulheres; ou pessoas simples, que se identificam com a igreja dos pobres, bem como comunidades de base em cidades, grupos da pastoral operária e da pastoral da juventude, partidos políticos e organizações não governamentais etc. As romarias podem reunir de cinco a setenta mil pessoas. A duração de uma Romaria da Terra varia de lugar para lugar. Normalmente ela dura um dia. Mas, houve também lugares em que ela chegou a durar três ou sete dias ou, inclusive, três semanas.

Para a Romaria, os participantes se organizam em grupos em suas comunidades. Muitos se preparam em relação ao tema escolhido para a planejada Romaria com alguns meses de antecedência a partir do material distribuído pela CPT. O tema de uma Romaria escolhido levando-se em conta a realidade da região, na qual a romaria é realizada. Os temas escolhidos podem ser: a reforma agrária, a ajuda para o desenvolvimento de pequenas empresas rurais, a falta de escolas ou 
a expulsão de algum grupo de sua terra ou a construção de uma barragem e a destruição da terra pelo alagamento daí decorrente.

Minha pesquisa se concentrou nas Romarias da Terra do estado do Paraná, por motivos práticos. Além de ser uma romaria mais aberta à participação da minha igreja de origem, a Igreja Evangélica de Confissão Luterana no Brasil (IECLB) e de ser uma romaria desvinculada de um centro de peregrinação católico, por anos, era a romaria que o Pastor Walter tinha acesso e conhecimento e, além disso, ela havia sido registrada em vídeo, algo fundamental para uma pesquisa à distância como a minha. Ou seja, havia a possibilidade de eu me inteirar das romarias anteriores, assistindo suas filmagens. Pacotes de fitas de vídeo começaram a chegar em minha residência, na Alemanha. Vídeos que precisavam ser transcodificados para o sistema alemão, diferente do sistema brasileiro. Além desse motivo prático, fundamental para a pesquisa que estava empreendendo, a colaboração do então secretário da CPT do Paraná, Jelson Oliveira, foi fundamental. Assim, essa pesquisa se dá através de configurações sui generis: um brasileiro, descendente de emigrantes alemães, os quais eram também no séc. XIX agricultores empobrecidos em busca de terra, teólogo de uma igreja confessional luterana no Brasil, em Hamburgo, pesquisando sobre uma peregrinação brasileira, prioritariamente católica, de pequenos agricultores e sem-terras.

Até o ano de 2018, 31 Romarias da Terra foram organizadas e celebradas no estado do Paraná, sob a coordenação da CPT regional, dioceses, igrejas e movimentos sociais. Elas ocorrem uma vez por ano e duram um dia (geralmente um domingo em julho ou agosto). A maioria dos participantes provém de comunidades católicas. Contudo, um grupo não sem importância vem de comunidades de confissão luterana e poucos outros provêm de igrejas livres ou pentecostais. As Romarias sempre ocorrem em lugares marcantes e simbolicamente de importância no Estado, sendo que, em cada ano, o local é novo: eles podem ser um local apropriado por meio de ocupação, uma cooperativa bem sucedida, um lugar a cuja história pertença uma luta pela libertação do povo, ou também a capital, Curitiba, entendida como centro do poder.

Este artigo pretende revisitar o meu caderno de campo e descrever a Romaria da Terra que ocorreu no ano 2000, a 15ª . Romaria, na cidade de Curitiba, no Paraná. Os relatos tomam por base minhas observações registradas através do método da observação participante, descrição dos vídeos da própria romaria, análise de materiais utilizados como livro de liturgia, de cantos e outros e a des-

1 https://www.cptnacional.org.br/acoes/romarias/114-romarias-2018/4447-31-romariada-terra-do-parana-celebra-o-deus-que-acampou-entre-nos. 
uma análise descritiva e reflexiva sobre a função da romaria da terra

crição feita no livro Liturgia com os pés (ADAM, 2012). O objetivo do artigo é entender o que as peregrinações, como eventos litúrgicos, causam nas pessoas que dela participam. Entender que tipo de transformação uma peregrinação causa na pessoa e em grupos que se colocam a caminho. São muitos aspectos relevantes que uma peregrinação, como a romaria, oferecem para a análise teológica, litúrgica, sociológica ou antropológica, com vistas a entender o potencial transformador. Ninguém volta de uma peregrinação da mesma maneira que foi. Pretendo aqui abordar dois aspectos que, a meu ver, causam profundas transformações: o caminhar (o movimento, em si) e a memória, como formas de resistência e transformação de consciência pessoal e coletiva. Na primeira parte do artigo farei um descrição detalhada de uma romaria e na segunda e terceira partes analisarei os aspectos da memória e do movimento. Retomo novamente às romarias da terra como um exercício da memória em tempos políticos difíceis no Brasil. É tempo de organizarmos peregrinações, de nos por a caminho para dizer quem somos e assim proclamarmos a memória perigosa de Cristo em nome da justiça, da dignidade e da paz.

\section{A Romaria da Terra do Estado do Paraná - Curitiba}

Viajei semanas antes para a cidade de Curitiba, para participar da organização da $15^{a}$.. Romaria da Terra. Movimentos sociais, comunidades de base, grupos diversos pipocavam em todo o estado, preparando-se para a romaria. O ano 2000, como ano bíblico sabático, era um ano especial para os movimentos sociais e igrejas. Campanhas em nível mundial proclamavam e clamavam pelo perdão das dívidas econômicas de países e grupos. Igrejas e organizações sociais no Brasil estavam engajadas nesse movimento. O tema da romaria do Paraná daquele ano, "Promover a vida no campo sem dívidas", refletia esse sonho. Por esse motivo se escolheu a capital Curitiba com local da romaria. Era lá, no centro do poder econômico, político e religioso que o perdão das dívidas sociais devia ser reivindicado.

O texto básico da $15^{\mathrm{a}}$. Romaria sobre o tema das dívidas era lido e debatido em todo o estado. Eventos, principalmente em Curitiba, eram organizados, como a Semana da Terra, cine-debate do filme "Terra de Deus" (Iberê Cavalcanti, 1999), a Assembleia dos/das Lutadores/as do Povo, aconteciam em todos os cantos do estado. Na sede da CPT, em Curitiba, parecia estarmos em um formigueiro de gente. Ali se preparavam os detalhes da romaria, principalmente a organização de material e da infraestrutura da grande peregrinação (ADAM, 2012, p. 92ss.). 


\section{Chegada e liturgia de abertura}

Por volta das 7 horas da manhã reuniram-se homens, mulheres, jovens e crianças no início da larga Avenida Cândido de Abreu bem no centro da cidade de Curitiba, entre modernos arranha-céus, bancos, igrejas (entre elas a catedral católica) e prédios governamentais. Longas mesas com toalhas coloridas ofereciam aos peregrinos que chegavam um bom café da manhã: pão com manteiga, café e leite e maçãs. Naquela manhã fria e de neblina, os romeiros, ainda sonolentos, se aqueciam na chamada mesa da partilha. Muitos haviam passado a noite inteira no ônibus. De longe, ouvia-se música popular brasileira, proveniente de alto-falantes de um caminhão ${ }^{2}$. A música sempre de novo era interrompida pelo chamado Vamos aquecer esta cidade.

Depois do café da manhã, os romeiros passaram a movimentar-se entre o lugar do palco e do caminhão (caminhão é usado como palco de som para a condução do evento). Atrás do palco e do caminhão encontrava-se o palácio do governador. Ao lado do palco ficava a prefeitura e bem na retaguarda dos peregrinos, a catedral de Curitiba. Os três edifícios constituíam assim o triângulo do poder: governo do Paraná, governo de Curitiba e da igreja, nesse caso, a catedral católica. Os romeiros da terra, que segundo a CPT eram em torno de 15 mil pessoas, estavam no centro do poder. Muitos deles eram jovens. Homens e mulheres na idade entre trinta e quarenta anos, assim como crianças e pessoas idosas também se encontravam presentes. Além disso, percebia-se a unidade dos grupos que, no decorrer da celebração, acabaram por integrar-se num único grande grupo.

As bandeiras e os cartazes identificavam os distintos grupos. A maioria dos cartazes retratavam claramente o tema da Romaria, as dívidas sociais, como p. ex.: Não pagar a dívida externa é a solução dos problemas brasileiros; Lutamos por uma vida sem dividas no campo e na cidade; A luta por vida sem dividas é dever cristão. Outros cartazes ou bandeiras apontavam simplesmente para a localidade de origem do grupo ou o nome da paróquia ou ainda lembravam um mártir específico. Um grande cartaz lembrava com imagem e poesia o martírio do sacerdote e dirigente da CPT no norte do Brasil, Josimo Morais Tavares, assassinado em 10 de maio de 1986. Muitos participantes se cobriam com as bandeiras dos movimentos, como se a "vestissem". Típicos eram também os chapéus de palha ou os bonés do Movimento Sem Terra. Havia até uma tenda, num canto da Avenida Cândido

2 Tais caminhões, com potentes alto-falantes instalados, são típicos no Brasil. Os "Trios Elétricos", como são denominados, normalmente são usados nas ruas durante o carnaval, como um tipo de palco móvel. Uma banda toca no "Trio Elétrico" pelas ruas da cidade, e as pessoas acompanham o caminhão dançando. 
de Abreu, em que se podiam comprar os chapéus de palha. Em dado momento vieram jovens e distribuíram crachás com barbantes, nos quais constavam o tema da romaria, a data e um espaço para a colocação do nome de cada pessoa. Outros jovens distribuíam as folhas de cantos, de quatro páginas, com 39 hinos e cânticos, nas quais constavam a identificação da Romaria com tema e data, um resumo da estrutura litúrgica e algumas informações sobre o percurso da procissão e abertura.

Sobre o caminhão se encontravam cerca de 15 dirigentes e os músicos da celebração. As dirigentes eram as únicas que portavam vestimenta diferenciada, i.e., as camisetas da romaria em amarelo e chapéus e também crachás identificado como Liturgia. Toda a condução da celebração e todas as falas e leituras foram feitas dos microfones desse caminhão. Iniciando a celebração, o então pastor sinodal da Igreja Luterana - Edgar Ravache - e três bispos da Igreja Católica Dom Sérgio Braske, Dom Pedro Fedalgo e Dom Ladislau Bienascchi - saudaram os peregrinos e abriram oficialmente a $15^{a}$ Romaria da Terra:

Declaro aberta a $15^{\text {a }}$ Romaria da Terra do Paraná [...] Tudo o que fazemos hoje aqui, vamos fazer em nome do Deus da vida, aquele Deus que caminhou com o povo, do Egito para a Terra Prometida, e lá todos receberam a sua terra, de acordo com o número das famílias de cada tribo. Hoje também Deus continua caminhando com todos, também com o povo da terra, também com o povo sem terra, também Ele quer que todas as dívidas do campo sejam resgatadas, que o lavrador tenha escola, que viabilize o seu trabalho na terra, que ele tenha apoio também no financiamento viável (Descrição de vídeo, p. 6).

Normalmente o palco da Romaria se encontra sobre o caminhão. Desta vez, contudo, foi montado um palco especial (de, aproximadamente, 1,5 metros de altura por 15 metros quadrados de comprimento) na frente do caminhão. No centro do palco encontrava-se um grande monte de terra. Em torno desse monte de terra desenvolveu-se toda a primeira parte da $15^{a}$ Romaria da Terra. O clima entre os romeiros era de encontro, muita conversa, abraços, cantos e acenos com as mãos, chapéus e bandeiras. Eu tinha a impressão permanente de estar participando de algo grandioso.

\section{Saudação da mãe-terra}

Depois das palavras de saudação e de abertura, a oração de abertura constituiu a primeira ação de caráter litúrgico da $15^{\text {a }}$ Romaria da Terra. O ritual da saudação à mãe terra introduziu um momento diferenciado na celebração. O discurso e os gestos de caráter mais informal dão espaço para performances, apresentações 
e encenações. Formou-se uma passagem no meio das pessoas participantes, para a qual convergiram as atenções de todos. Uma música instrumental-eletrônica foi tocada e quinze mulheres, vestidas com batas azuis e tendo as cabeças adornadas com coroas de girassóis, carregavam vasos de barro com água. Ao mesmo tempo uma voz feminina lia no microfone: No princípio criou Deus os céus e a terra. A terra, porém, estava sem forma e vazia; havia trevas sobre a face do abismo, e o Espírito de Deus pairava por sobre as águas (Gn 1.1). As mulheres subiram ao palco e despejaram a água dos jarros na direção do público, como forma de representar a separação entre terra (sobre o palco) e a água. Depois disso, elas voltaram para o corredor central e passaram a abençoar o povo com o restante da água dos vasos, aspergindo-a com ramos verdes sobre a multidão.

\section{Invocação}

A seguir, fez-se a invocação do Deus da terra e da vida, feita de forma trinitária-inter-religiosa, de acordo com a oração constante nas folhas de cantos. Conduzida a partir do microfone do caminhão, todos leram juntos:

Em nome do Deus de todos os nomes, Javé, Obatalá, Olorum, Oió. Em nome do Deus que a todos os homens, nos faz da ternura e do pó. Em nome do Pai que fez toda carne: a preta e a branca, vermelhas no sangue. Em nome do Filho, Jesus, nosso irmão, que nasceu moreno da raça de Abraão. Em nome do Espírito Santo, bandeira do canto do negro folião. Em nome do Deus verdadeiro, que amou-nos primeiro sem dividição. Em nome dos Três, que são um Deus só, aquele que era, que é, que será. Em nome do povo que espera, na graça da fé, à voz do Xangô, O Quilombo-Páscoa, que o libertará. Em nome do povo sempre deportado pelas brancas velas no exílio dos mares; marginalizado no cais, nas favelas e até nos altares. Em nome do povo que fez seu Palmares, que ainda fará Palmares de novo: Palmares, Palmares, Palmares, do povo! (Missa dos Quilombos).

Durante essa parte já acontecia algo novo em meio à passagem, rumo ao grande palco. Cinquenta crianças, vestidas com batas brancas, portando flores nas mãos, entravam pelo corredor. Ouve-se então a música Em nome de Deus, de Milton Nascimento, o texto da invocação de Deus, que acabara de ser proferida. As primeiras dez crianças portavam a faixa com o tema da $15^{\mathrm{a}}$ Romaria da Terra: Promover a vida no campo sem dividas. As crianças posicionaram-se ao redor do monte de terra sobre o palco, em que plantaram as flores. O gesto foi explicado pela equipe litúrgica como ato da criação de Deus. As flores deveriam simbolizar a 
uma análise descritiva e reflexiva sobre a função da romaria da terra

fertilidade da terra. Após referida ação, as crianças - com exceção de três delas deixaram o palco e a invocação Em nome de Deus é repetida por todos os romeiros.

Logo após começou uma música instrumental e pelo corredor vieram dezoito jovens, moças e rapazes, de mãos dadas, vestidos de túnicas e calças coloridas. No palco eles e elas dançavam ao redor do monte. Durante a dança, três crianças da apresentação anterior, que ainda haviam permanecido ao redor do monte, soltaram de uma gaiola cinco pequenos passarinhos. Os passarinhos voaram de forma rasante em direção à multidão, buscando guarida junto às árvores da Avenida Cândido de Abreu. Durante esse momento, os participantes bateram muitas palmas.

Alguns jovens abandonaram o monte sobre o palco atrás de uma fumaça de cor vermelha. Um rapaz e uma moça, envoltos em tecidos e materiais sintéticos, saem repentinamente do centro do monte, representando assim a criação do ser humano, ao som das Quatro estações, de Vivaldi. Os demais jovens dançaram ao redor do monte e do jovem par e levantaram as flores plantadas no monte. Ouviam-se os fogos de artifício atrás do palco e do caminhão. A música de fundo passa a ser Halleluja do Messias de Händel. O par foi acolhido com abraços no meio do círculo dançante.

Pelo corredor de entrada apareceu um grupo dançante de sete indígenas, com adornos na cabeça, chocalhos e rostos pintados. Tocando seus instrumentos e cantando suas músicas, o grupo subiu no palco e lá permaneceu, silencioso. Uma das mulheres trouxe consigo um bebê. Após essa entrada, o presidente nacional da Comissão Pastoral da Terra, Dom Thomas Balduino, fez uso da palavra³:

Bendito sejais ó Pai, Criador... do universo... e criou o homem e a mulher... Criou este jardim chamado terra para que cuidássemos dele e levássemos à perfeição a comunhão entre os homens e as mulheres, entre as aves, os peixes, as plantas, todos os animais, entre as águas e o ar que nós respiramos. Bendito sejais ó Pai, abençoai esta nossa caminhada, como abençoaste a caminhada do povo de Israel partindo do Egito, da escravidão ... pra terra da libertação e reconciliação, onde corria o leite e o mel. Libertai-nos do Faraó, do Faraó do Egito e de todos os Faraós que impedem a caminhada do vosso povo. Queremos, ó Pai, assumir esta missão de cuidar da terra...de ser uma terra onde plantamos as flores ... as margaridas, o milho e o arroz ... e recuperar a vida, sobretudo a vida no campo, onde foi entregado o teu próprio filho Jesus ... junto com todos os povos, principalmente os indígenas, os negros e os sem-terras... e toda morte, e todo luto e toda a dor. Bendito sejais, ó Pai e

3 Lamentavelmente não é mais possível reconstruir das tomadas de vídeo todas as palavras proferidas por Dom Balduíno. 
Senhor da vida, Senhor do Céu e da Terra, Senhor do homem e da mulher, desta beleza que é o reflexo do vosso rosto, lindo, fraternal, terno e acolhedor. Bendito sejais para sempre, amém, aleluia (quase um grito), amém.

Depois dos índios, seguiu-se um grupo de negros, que cantavam, brincavam e dançavam capoeira, fazendo o mesmo percurso do grupo anterior. Um terceiro grupo a subir no palco foi de italianos. Tratava-se de um grupo profissional de danças italianas da região, com trajes típicos. Música italiana era tocada quando de sua entrada. Nesse momento, enquanto era cantado o hino de $15^{\mathrm{a}}$ Romaria da Terra, os três povos encenavam o cultivo da terra, trabalhando com as ferramentas o monte de terra sobre o palco. Com enxadas, distribuíam a terra por todo o palco. Depois disso, os três grupos abandonaram o palco.

\section{Bíblia e o símbolo da romaria}

Em seguida, a Bíblia e o símbolo da $15^{a}$ Romaria da Terra - uma carroça com duas pipas de vinho - são conduzidos pelo corredor central, cuja explicação era:

Animador 1: Somos um povo peregrino no caminho da esperança. Somos um povo que resiste na construção de alternativas. Um povo que descobre caminhos [...]. Por isso queremos agora acolher o símbolo desta $15^{\text {a }}$ Romaria da Terra do Paraná: a carroça carregada com o vinho da alegria, o vinho da festa, produto da terra e das mãos dos homens e das mulheres que cultivam o fruto e alimentam o povo. Animador 2: A carroça chega do município de Colombo, a maior colônia italiana do Paraná, lembrando todas as etnias que fundaram a cidade de Curitiba [...]. Animador 3: A carroça traz a Bíblia, Palavra de Deus que ilumina o caminho do povo na denúncia das dívidas sociais e no anúncio da dignidade humana e da paz. [...] Na Bíblia, a mensagem do Jubileu da terra e dos seus povos significa a restauração do projeto inicial de Deus, que é vida para todos/as. (Caderno de liturgia, p. 3).

Durante essas palavras, a carroça de quatro rodas, puxada por dois cavalos brancos, entrava pelo corredor. $\mathrm{Na}$ frente da carroça ia novamente o grupo de danças italiano. A carroça, típica para o uso em regiões agrárias, era conduzida por um senhor idoso, vestido de preto e portando um chapéu escuro. Sobre a carroça encontravam-se duas grandes pipas de vinho. Na pipa de trás estava sentada uma mulher, com trajes italianos típicos, trazendo a Bíblia. A Bíblia aberta encontravase sobre a parte de trás de uma grande enxada de madeira (como um púlpito), adornada com fitas coloridas e um chapéu de palha. Na parte bem ao fundo da carroça se encontrava uma bandeja cheia de frutas. Enquanto chegava a carroça, 
uma análise descritiva e reflexiva sobre a função da romaria da terra

todos cantaram um dos mais típicos hinos da Romaria da Terra, em cujo refrão consta: Romaria da Terra, faz o povo reunir; numa luta sem guerra, nós lutaremos por ti.

Uma mulher desceu da carroça e subiu no palco com a enxada e a Bíblia. Aos fundos o grupo italiano dançava a danza del ombrello enquanto que a mulher apresentava aos romeiros a Bíblia aberta sobre a enxada. O grupo folclórico agora dançava sobre a terra que fora anteriormente representativamente cultivada. Depois da dança, todos aclamaram a Bíblia com o hino A Palavra de Deus já chegou (Folha de Canto, nr. 22).

Padre Zenildo, ao microfone do caminhão, fez a leitura do texto bíblico de Habacuque 2,6b-12. Os coordenadores explicaram que o texto pertencia às denúncias dos profetas que, no contexto da romaria, expressavam um claro protesto contra os poderosos do Brasil, conclamando à crítica do modelo socioeconômico representado, aqui, por Curitiba.

Denúncias e dívidas

$\mathrm{O}$ texto de Habacuque introduziu um momento completamente novo na romaria, sem, contudo, quebrar a sequência do todo. O projeto de Deus, baseado na história da criação, foi destruído, razão pela qual existem no campo e na cidade grandes dívidas sociais, que necessitam ser mostradas e apresentadas no centro do poder. A capital não somente encobre as consequências do seu modelo em suas periferias, mas Curitiba esqueceu-se progressivamente do seu entorno. Por isso, as denúncias da romaria são feitas usando carrinhos de mão. Explicou-se que os carrinhos de mão foram usados na construção da cidade. Aqui não eram mais empurrados com cimento e tijolos, mas cheios de terra proveniente das diferentes localidades para as quais a Romaria havia conclamado os romeiros durante os últimos 14 anos. Por uma bandeira, sobre a qual constava o nome do lugar, eram identificados os 14 diferentes tons de cor avermelhada (cor típica no estado) da terra. Assim se anuncia esse novo momento:

[...] Aqui, no coração da cidade, onde gira a engrenagem enferrujada do poder, trazemos o sangue, a dor e a resistência dos trabalhadores e trabalhadoras de nosso Estado. Certamente os gabinetes dos governos querem ignorar este sofrimento. As nossas pequenas e esquecidas comunidades do interior do estado não existem na geografia do poder. [...] Mas estamos aqui hoje, para dizer que existimos, que resistimos, que insistimos em viver com dignidade. Estamos aqui para denunciar as dívidas sociais [...]. Durante 14 anos celebramos juntos as dores e as vitórias dos trabalhadores e trabalhadoras do campo. Pra que esta Romaria seja uma estação da ressurreição, é preciso resgatar as dívidas sociais. Só haverá vida e ressurreição se houver dignidade 
humana e paz para todos. [...] Por isso, estas 14 terras são memória, são compromisso e são esperança. 14 gritos do povo. 14 gemidos de medo. 14 anos de caminhada [...] As terras são trazidas nos carrinhos-de-mão, as carriolas, símbolos da construção desta cidade e memória de todos os seus construtores, homens e mulheres que construíram mas não moram [...]. (Caderno de liturgia, p. 4).

A procissão dos carrinhos de mão pela passagem foi lenta, chamando à reflexão. A atmosfera entre os participantes passou para uma atenção silenciosa e observação concentrada. Os participantes cantaram juntos o canto "Eu venho de longe, en sou do sertão. Sou Pedro, sou Paulo, Maria e João, en sou brasileiro, mas sou estrangeiro, lutei pela pátria e ganhei cativeiro! E agora me digam se eu tenho direito, se sou cidadão, ou por Deus não fui feito?" (Folhas de canto, nr. 10).

Do caminhão, leu-se então, o discurso de abertura e as dívidas sociais de cada uma das Romarias. Durante a leitura das diversas dívidas, os correspondentes carrinhos de mão eram levados para o palco. O segundo carrinho de mão lembrou a violência e a impunidade no campo. Foi sugerido um minuto de silêncio para lembrar a expulsão dos sem-terras do local e o assassinato de Antônio Moraes Tavares, na entrada de Curitiba, por ocasião de uma demonstração, em maio daquele ano. Antônio? Onde estás, Antônio? Tu estás presente! Antônio? Pergunta e resposta foram repetidas três vezes. A resposta foi sempre um alto grito conjunto e indignado: Presente! No final dessa parte, todos os 14 carrinhos de mão formaram como uma fachada na parte da frente do palco. A confrontação com as dívidas era, agora, concretamente representada. Elas possuíam origem, nome, história e rostos. A seguir, a romaria denunciou a dívida de todas as outras dívidas, que representa a raiz de todas as demais: passou-se a falar da dívida externa, tão grande, tão absurda e tão pesada como a cruz de Jesus Cristo: “[...] Por isso, a cruz da $15^{\text {a }}$ Romaria da Terra do Paraná é a cruz de um país crucificado, à espera da ressurreição. É uma cruz de sofrimento e da dor de um país roubado e de um povo enganado. Cruz de uma bandeira amarrada pelas cercas do latifúndio [...]." (Caderno de liturgia, p. 8s.).

\section{A cruz}

A grande cruz de madeira, de aproximadamente 4 × 3 metros, sobre a qual havia sido pregada uma bandeira do Brasil, foi carregada por 4 homens pelo corredor. Os participantes estendiam um braço na direção da cruz, como se quisessem tocá-la ou ser tocados pelo seu poder. Durante essa apresentação, foi cantado o Pai-Nosso (Folhas de Canto, nr. 34). Só no palco a cruz foi erguida à frente da 
uma análise descritiva e reflexiva sobre a função da romaria da terra

fachada dos carrinhos de mão. Como as 14 dívidas no palco, a cruz encontrava-se aqui na parte da frente, defronte aos participantes. Como de costume, a oração era proferida ao microfone, a qual os participantes acompanhavam reverentemente, tirando os chapéus e esticando os braços na direção da cruz.

\section{A ressurreição e a resistência}

A seguir, passou-se a proclamar a ressurreição de Cristo ao microfone com as palavras Cristo não morreu, ele ressuscitou e por isso o Brasil também precisa ressuscitar! Enquanto isso, um dos homens que carregava a cruz arrancou dela a bandeira brasileira, pregada na cruz. O povo aplaudiu com grande entusiasmo. Depois disso, cantou-se o hino Liberdade (Folhas de cantos, nr. 17).

No centro do poder, os romeiros não só desejavam proclamar em alta vOz as suas denúncias, mas também os êxitos das 14 romarias e da luta por terra no Paraná. Mesmo sem o apoio do governo, eles resistiram com sua alternativa, como será dito no microfone: "A Palavra do Senhor é palavra de vida, é semente, é broto. Palavra de vida é palavra de esperança. Por isso, da terra que trouxemos do interior do Paraná nasce a esperança no novo projeto de sociedade que nós queremos. Da terra nascem as alternativas de vida e de libertação do povo de Deus." (Caderno de liturgia, p. 11).

Com esse discurso principiava o final da primeira parte da $15^{a}$ Romaria da Terra. Os 14 carrinhos de mão ainda se encontravam sobre o palco. Debaixo da terra de cada carrinho encontravam-se encobertos aproximadamente 30 metros de faixas, nas quais constavam palavras-chaves relacionadas à ressurreição: direitos, formação, saúde, meio ambiente, Evangelho da vida, reforma agrária, entre outras. Para cada dívida era mostrado um êxito concreto por intermédio da narração de uma experiência do dia a dia nas organizações, igrejas e nos movimentos. Durante o discurso, eram desenterradas faixas de diferentes cores com a correspondente palavra e desdobrada sobre o palco e estendida até o meio das pessoas, que as seguravam. Os romeiros seguravam as faixas de diferentes cores. Depois da exibição de cada faixa, grandes grupos dos respectivos projetos dirigiram-se pelo corredor de passagem, de trás para frente, em direção ao palco. Os grupos vinham com suas bandeiras, cartazes e faixas. Eles foram convidados a dirigir-se para frente enquanto se cantava o refrão do hino Bandeira de luta (Folhas de cantos, n. 11). Dessa maneira, as bandeiras dos projetos, das organizações, das pastorais e dos movimentos ocupam o centro do evento.

Depois de, aproximadamente, três horas, chegava ao seu final a primeira parte da $15^{a}$ Romaria da Terra. 


\section{A caminhada}

Como se o centro do poder não pudesse oferecer solução melhor, os romeiros começaram a procurar por soluções próprias. Eles abandonaram o centro do poder e marcharam pela cidade na direção da pedreira Paulo Leminski como local de uma autêntica festa ${ }^{4}$. Por um pequeno momento em que os romeiros tocavam os ombros de seus vizinhos com uma de suas mãos, eles silenciaram e escutaram a motivação para a caminhada:

Estas são as alternativas que o povo constrói no seu dia a dia. Não são apenas estas. Há muitas outras que nasceram e outras mais que precisam nascer. Por isso, o nosso projeto ainda não está pronto e precisamos caminhar. A nossa festa não é neste lugar. Para chegar no lugar da festa, a terra prometida, o povo de Deus precisou atravessar o deserto. [...] (Caderno de liturgia, p. 13).

Depois disso os peregrinos da romaria iniciaram a caminhada de $5 \mathrm{~km}$ pelas ruas secundárias de Curitiba ${ }^{5}$. O caminho conduzia por alguns bonitos arranhacéus, ainda no centro, parte de uma área rica da cidade, e por fim, também por uma área de classe média, mas não pela periferia ou pelas favelas da capital. A pedreira constituía-se de um grande abertura no solo, no qual antigamente eram talhadas pedras. Atualmente situa-se numa região turística e verde da cidade, ao lado da moderna ópera de arame. Essa cratera de pedra foi transformada num teatro ao ar livre com um palco fixo num dos lados, recebendo o nome de um famoso poeta de Curitiba, Paulo Leminski.

Às $10 \mathrm{~h}$ da manhã já fazia um sol quente sobre Curitiba. Os romeiros caminhavam pelo longo trajeto como um rio repleto de gente. A procissão tinha uma configuração tradicional, assumida espontaneamente pelos participantes, como se tivesse que ser assim: bem à frente, o símbolo da Romaria - a carroça com duas pipas de vinho e a Bíblia sobre a enxada, depois, logo atrás, uma bandeira do Brasil, de cerca de 10 x 7m de tamanho, carregada por jovens. Eles levantaram a bandeira, segurando-a como a um pano hasteado. Depois da bandeira vinha Dom Tomás Balduíno, então bispo e presidente da CPT. A ele seguia-se a faixa, com o tema da Romaria. Então vinha uma multidão de romeiros e romeiras e,

4 Diferentemente que em Romarias anteriores, a pedreira Paulo Leminski (uma arena open air) não possui uma importância implícita para a luta por terra. A função da pedreira é representativa, i.e., é construída uma relação com os propósitos da $15^{a}$ Romaria da Terra. A pedreira é expressão para um lugar diferente, lugar de festa, em oposição ao centro do poder.

5 Não foi emitida permissão para marchar pelas ruas no centro da cidade. 
uma análise descritiva e reflexiva sobre a função da romaria da terra

depois deles e delas a cruz era carregada por 4 homens. Os homens se revezavam espontaneamente nesta tarefa de carregar a cruz. Muitos peregrinos caminhavam perto da cruz, de modo que de longe praticamente não era possível vê-la. No meio do desfile encontrava-se o som do caminhão, a partir do qual era indicado o caminho a trilhar, gritos de guerra, falas e os cantos e hinos. Policiais iam de motocicleta na frente e na parte posterior da massa dos peregrinos, bloqueando o trânsito urbano nos cruzamentos. Bem ao final da marcha, vinha, preventivamente, uma ambulância. Com exceção dos carrinhos de mão, todos os elementos utilizados na primeira parte foram levados junto na caminhada.

Os romeiros levaram suas bandeiras e seus cartazes. Caminhavam tão perto uns dos outros que, por vezes, ficava difícil ler os cartazes. Além disso, eles carregavam suas sacolas ou bolsas com a comida do dia. Por causa do calor, penduravam suas grossas capas ou pulôveres nas bolsas ou as amarravam ao redor do corpo. As crianças também eram carregadas. Alguns romeiros conversavam entre si, outros comiam maçãs ou algo que havia sido comprado no caminho, outros ainda iam silenciosos e atentos. Do caminhão seguidamente eles eram instruídos a caminhar pela rua e não pela calçada. Essa indicação, aparentemente banal, expressa um importante gesto de luta: ocupadas devem ser as ruas da cidade, em vez dos espaços normais reservados aos pedestres.

Duas vezes foi orado o Pai-Nosso, uma vez diante de um hospital para os doentes. Ali também houve oração em prol de melhorias no sistema de saúde precário do Brasil. Uma vez foi sugerido dar-se mutuamente o abraço da paz. Muitos o fizeram naquele momento. A marcha era tão extensa que, bem à frente ou bem atrás, dificilmente se ouvia algo do que era transmitido pelos alto-falantes do caminhão.

A procissão de cerca de duas horas de duração não teve um momento especial de parada, as conhecidas estações, como é comum. Parece-me que o especial aqui foi o próprio caminhar, o fato de ocupar a capital com os pés dos pobres da terra. O estar a caminho significou uma grande passagem entre o centro excluído do poder e o local da festa e das novas possibilidades.

\section{A festa da partilha}

A pedreira não é naturalmente o local especial para a memória e a celebração do povo da terra como nas Romarias passadas, em que o local de chegada se encontrava em relação direta com as lutas políticas do povo como sinal de resistência dos pobres da terra, como foi o caso, p. ex., de uma cooperativa de pequenos agricultores na $13^{a}$ Romaria da Terra. A pedreira Paulo Leminski é, bem 
ao contrário, o local de uma certa elite cultural, que pouco tem a ver com o povo da romaria. Justamente devido a este contraste, a pedreira se transforma em local especial: sua ocupação pelos pobres da terra representa uma ação importante.

A carroça chegou por primeiro na pedreira. Os cavalos foram soltos e foram pastar. Os romeiros chegaram ao local da festa cansados e procurando por sombra. Rapidamente procuraram por um espaço para comer em pequenos grupos. A atmosfera era a de uma grande festa e se tinha a boa impressão - talvez por causa do claro limite devido às paredes da pedreira - de estar num espaço protegido e de pertencer à massa. Os responsáveis não dirigiam o evento como de costume, do caminhão, mas tomaram posição sobre o palco da pedreira. Atrás do palco estavam penduradas as 14 faixas, desenterradas dos carros de mão com as conquistas do povo da terra. Sobre o palco também se encontravam os instrumentos musicais.

\section{O almoço}

A primeira atividade conjunta na pedreira foi a oração do Pai-Nosso em sua versão ecumênica. Depois disso passou-se para o almoço conjunto. Do palco veio o convite para elevar os alimentos trazidos, a fim de receber a bênção para a refeição. Sentados no chão, as pessoas estenderam, na direção do palco, suas panelas, embalagens, sacos ou as garrafas de refrigerantes, sucos ou água e ouviram atenciosos a bênção sobre a comida. Embora houvesse comida para comprar em pequenas barracas, a grande maioria havia trazido sua própria refeição. Tudo foi dividido em pequenos grupos, sentados no chão. A atmosfera era bem festiva e descontraída.

Durante o almoço, cinco mulheres, do grupo negro Ka-Naombo, apresentaram danças africanas no palco. Uma das mulheres declamou uma poesia sobre a cultura negra. Uma hora depois, deu-se prosseguimento à celebração.

\section{Os cinco princípios de um projeto alternativo para a sociedade}

A apresentação dos cinco princípios de um projeto alternativo para a sociedade iniciou com a oração: Nós somos este país, assim denominada na estrutura litúrgica. Com essa oração, a CPT tencionava despertar a esperança por um projeto popular, a ser baseado em cinco princípios sociopolíticos: soberania, sustentabilidade, democracia, desenvolvimento e solidariedade.

[...] A Pedreira leva o nome de um grande poeta curitibano que denunciou a arrogância e ironizou sobre as elites atrasadas do Paraná. Por isso, sob 
uma análise descritiva e reflexiva sobre a função da romaria da terra

os versos de Paulo Leminski, transformamos hoje este lugar num lugar do banquete dos excluídos. [...] Por isso, queremos aqui fazer a festa do povo nesta grande Romaria da Terra. Festa legítima e justa daqueles que produzem as riquezas e que não usufruem dos bens produzidos. [...] A $15^{\mathrm{a}}$ Romaria da Terra anuncia o nascimento de um novo tempo: tempo de plantar sementes, de colher os frutos e celebrar a vida. Sementes de um novo Brasil [...] (Caderno de liturgia, p. 14).

Em cinco lugares, na parte alta das paredes da pedreira, encontravam-se penduradas faixas com cerca de 30 metros de comprimento, nas quais se encontravam escritos os cinco princípios do projeto. As faixas com as correspondentes palavras do novo projeto - soberania, sustentabilidade, democracia, desenvolvimento - foram associadas cada qual com uma das cores da bandeira brasileira branco, azul, amarelo e verde. Adicionalmente veio, por fim, a faixa de cor extra, em vermelho, com a palavra solidariedade. Os romeiros são convidados a olharem na direção das diversas faixas. Depois da leitura e explicação do correspondente princípio, cada uma das faixas na parede foi desenrolada de cima para baixo, de forma que o conceito correspondente pudesse ser revelado.

Do chão, sob as faixas, subia fumaça com cores que correspondiam a elas, e grupos de jovens se movimentavam de lá em direção à massa. Os jovens usavam túnicas da mesma cor das correspondentes faixas e chapéus de palha. Dançando eles chegaram ao centro da multidão, e no caminho distribuíam sementes na cor das respectivas faixas. Depois de cada repetição desse ato dos jovens, era cantado o hino Juventude, cujo refrão tem os seguintes dizeres: "Paz na terra, meu irmão. Paz a quem tem boa vontade, paz no campo e na cidade. Paz é coisa que se faz na partilha deste pão, que nos faz uma família, paz irmão, eu preciso de tua paz" (Folhas de canto, n. 38). Ao centro os jovens formaram progressivamente uma grande e viva bandeira do Brasil.

Ao final desse ato, encontrava-se, no meio da multidão, a bandeira do Brasil, composta de pessoas. A seguir foi cantado o hino Ordem e Progresso ${ }^{6}$. Enquanto isso, a bandeira era desfeita e os jovens se misturavam entre os demais peregrinos.

\section{A festa autêntica}

A festa dos excluídos ou a festa autêntica, da qual se falava desde o início da romaria, começou somente com esta parte, mesmo que essa visão e esperança já cunhassem a romaria desde o início. Essa parte, intitulada na liturgia de festa

Ordem e Progresso são as palavras escritas sobre a bandeira brasileira. 
dos pobres, desenvolveu-se como uma mescla de três elementos: 1) O texto bíblico de Lc 14.12-24, sobretudo, a parábola da grande ceia, em que os excluídos da sociedade são convidados para um banquete, recusado pelos ricos por falta de interesse ou tempo; 2) O vinho, símbolo da $15^{\text {a }}$ Romaria da Terra, designado como elemento principal da festa; 3) O show de samba da cantora popular Leci Brandão e sua banda.

Os pobres da terra são os convidados de Deus, porque têm a responsabilidade e se encontram diante do desafio de construir uma nova sociedade segundo os cinco princípios: "No Banquete do Reino os excluídos são os convidados, porque sempre dispostos a atender ao chamado de Deus, enquanto ricos e poderosos estão sempre muito ocupados com seus afazeres. Por isso vamos partilhar o vinho da alegria dos pobres que celebram a conquista da dignidade." (Caderno de liturgia, p. 21).

Os participantes foram convidados a tirarem o seu chapéu, a fim de ouvir a leitura bíblica. Frei Sérgio segurou a Bíblia em seu chapéu e leu o texto de Lucas. Durante a leitura, começou a distribuição do vinho. Muitos peregrinos seguravam com uma mão seu chapéu e com a outra os seus copos de plástico com vinho, ouvindo atentamente a leitura. Nesse momento, a atmosfera estava cunhada por grande concentração e silêncio meditativo. Depois da leitura, teve início o show de Leci Brandão.

Leci Brandão ficou conhecida pela sua música crítica de samba, em que também canta sobre problemas sociopolíticos. Justamente por isso ela talvez não seja tão conhecida pelos meios de comunicação de massa. Sua banda negra, composta por cinco pessoas, foi fundada na escola de samba da Mangueira, no Rio de Janeiro. Leci Brandão tem uma incrível capacidade para interagir com o público. A música de alta qualidade traduzia os conhecidos temas da CPT e da Romaria da Terra. O show não foi só acompanhado de forma estática pelo público, mas foi vivenciado e saboreado. Ao seu show também pertenciam a dança, o ato de fumar, o flerte e a erótica.

Durante o show, os romeiros povoaram todo o palco. Era um show para os peregrinos e dos peregrinos. Eles subiram ao palco, dançaram e cantaram juntos. Não havia limite de proximidade, nem para fazer fotos ou, inclusive, ter contato físico com os músicos. No final do show, Leci Brandão sugeriu que todos se dessem as mãos e cantassem junto a famosa Canção da América, de Milton Nascimento. Essa música emotiva trouxe um momento interativo e estimulante, uma vez que todos os participantes, com os braços e mãos sobre os ombros dos outros, formaram uma grande corrente. 
uma análise descritiva e reflexiva sobre a função da romaria da terra

\section{Ação, bênção e pedra}

Depois de Leci Brandão ter deixado o palco, convocaram-se todos os bispos, sacerdotes e pastores para o palco, para proferir a bênção. Ao bispo Dom Pedro Fedalgo foi cedida a palavra:

[...] A terra é uma bênção de Deus, a terra deve ser de todos... Vamos pedir ao Senhor para que contemple a reforma agrária para que haja terra para todos, para que haja uma agricultura, uma política agrícola, para que todos tenham uma vida digna [...] Vamos pedir para que resgate todas as dívidas, culturais, sociais, para que haja escola para todos [...] Bendito seja Deus, bem aventurados sejam todos vocês (Descrição de vídeos, p. 23).

A seguir foi explicado o símbolo de recordação da Romaria, as pedras empacotadas. Em todos os lugares, no chão da pedreira, havia pequenos montes de tais pedras, embaladas em pequenos saquinhos plásticos, fechados com o tema, data e local da romaria. Precisava-se cuidar para não pisar em cima de algum deles. Muitos já seguravam suas pedras com as mãos. Outros procuraram uma pedra no momento em que o símbolo de recordação era explicado. Os romeiros foram convidados por microfone a segurar uma pedra na mão e estendê-la em direção ao palco. A outra mão deveria ser colocada sobre os ombros de um vizinho. Então, Frei Sérgio, em nome de todos os demais religiosos, proferiu a bênção:

[...] Nossa gente é a pedra rejeitada pelo projeto do deus-mercado na construção do seu reinado. Assim como teu filho, ó Pai, acreditamos que os pobres do campo e da cidade são as pedras fundamentais para a construção de um projeto popular. Por isso, Pai de infinita ternura, derrama sobre nós a força do teu Espírito, infunde em nossos corpos, almas e espírito o desejo ardente de construirmos juntos este projeto popular, que será sinal do teu reino no meio de nós. Por Cristo, Senhor e nosso Irmão Libertador, Amém, Amém! (Descrição de vídeos, p. 25).

Durante a bênção os participantes estavam muito concentrados. No final pediu-se que eles beijassem a pequena pedra e a dessem para alguém. Dessa maneira eles trocaram as pedras uns com os outros. Muitos participantes levaram consigo várias pedras, para presenteá-las em casa a outras pessoas.

No meio da multidão foram soltos centenas de balões nas cores da bandeira brasileira. Pela última vez, cantou-se o hino da romaria. Foi a ocasião em que todos se abraçaram e despediram. Dessa forma encerrou-se a $15^{a}$ Romaria da Terra do Paraná após essa última parte, que durou aproximadamente três horas. 
Rapidamente os romeiros deixaram a pedreira, em direção aos seus ônibus. Sobre o palco se abraçavam os religiosos, comemorando com os coordenadores, músicos e organizadores o término de mais uma Romaria da Terra.

\section{A Romaria da Terra como anamnese e memória perigosa}

O elemento da memória (ASSMANN, 2000) desempenha, nas Romarias da Terra, um importante papel: memória das romarias anteriores, seus locais, momentos, temas e denúncias, como as 14 dívidas e a dívida externa, em Curitiba. Memória tem relação com identidade, origens das pessoas e grupos, origem agrárias antigas, origens étnicas (negras e africanas, indígenas, italianas). Memória também ocorre quando se lembram os episódios violentos como expulsões de grupo e organização, a cidade como espaço de exclusão social, a memória dos mortos, como o assassinato de Antônio M. Tavares (CANDAU, 2018, p. 151ss.). As memórias são associadas às memórias da tradição bíblica e à memória da cruz de Cristo.

Memória, nas romarias, não consiste apenas em lamentar pelo passado trágico. Ela desperta a resistência, cria esperança e identidade (CANDAU, 2018). Em Curitiba, a cruz do sofrimento passa a transformar-se em cruz da esperança. Sair de um lugar de morte e ir para outro lugar, de vida e festa. Nesta tensão - memória-sofrimento-ressurreição-esperança - memória significa aqui uma acentuada denúncia e protesto e grande esperança simultaneamente. Normalmente a caminhada, a procissão propriamente dita, era considerada, em outras romarias, como o mais forte momento de protesto. Desta vez, é o protesto que é articulado na memória das dívidas e a procissão que vem a seguir é um desdobramento desse momento. Estar no centro do poder provavelmente tenha determinado essa mudança.

Os ritos de memória nas romarias reúnem, portanto, o político e o religioso num mesmo ato: não foi falado unicamente sobre as romarias anteriores, mas foram trazidos junto os nomes dos diversos locais. As dívidas sociais não foram só citadas, mas foram representadas simbolicamente pela terra dos locais. O modelo da cidade de Curitiba não foi só denunciado com palavras, mas representado pelos carrinhos de mão. Em vez do grito fervoroso de uma demonstração, reinaram aqui o silêncio e a progressão dos homens e das mulheres com os carrinhos de mão ao modo de uma procissão. A morte de Antônio, ocorrida naquele ano, não foi só lamentada e evocada, mas o próprio Antônio foi dado como presente. Assim é que a memória é feita na romaria. 
uma análise descritiva e reflexiva sobre a função da romaria da terra

A memória não representou unicamente recordação do passado, mas atingiu também o presente e o futuro. Quando Antônio foi chamado, ele se fez presente. Pela ritualização, as diversas apresentações se faziam presentes, vivas. Esse momento preparou a estação da ressurreição com uma explosão de esperança pelas consequências dos 14 anos de luta por terra no Paraná. Dessa forma, a memória se tornava também ponte para o futuro. $\mathrm{Na}$ Romaria da Terra, a memória não é só trabalho mental, tradição ou papel impresso. Ela permite, muito mais, por meio de ações litúrgicas, em que passado e futuro se tornem presente. Onde pessoas foram expulsas de seus lugares e se encontram em busca de lugar e espaço, a memória torna-se em fonte de sobrevivência.

A memória evocada na romaria não é criada. Apela-se justamente para essa reserva de memória, para chamar o grupo à existência: "Uma verdade, para poder se fixar na memória do grupo, deve se apresentar na forma concreta de um evento, uma pessoa, um lugar (M. Halbwachs) (ASSMANN, 2000, p. 38)". Por isso ela é, a um só tempo, fonte de identidade e resistência, perigosa para os poderosos e, ao mesmo tempo, libertadora para os que se encontram a caminho, em romaria, em busca de espaço, de terra para viver. Como lembra Metz: "A escravização de pessoas começa com o fato de lhes ser tirada sua memória” (METZ ,1972, p. 402). Para os excluídos, a memória tem uma função contrapresente: "Ela parte de experiências de deficiência do presente e roga na memória por um passado que geralmente possui os contornos de uma época heróica" (WOORTMANN, 2001. p. 194s). Na Romaria da Terra, essa época heróica é procurada no passado de um modelo de vida simples no campo ou no mito bíblico, sendo que o ritual da criação no início de toda romaria é evocado com esse propósito. Mas essa memória germina o presente e o futuro, animando a festa ao som de samba, com vinho e projetos alternativos de esperança.

$\mathrm{Na}$ Romaria da Terra está presente ainda outra forma de memória. Ela tem a ver com a articulação por meio de tradição cristã litúrgica ex memoria passionis Christi, o que Metz denomina de Memória do sofrimento.

Ela reclama história não só como cenário de projeção de interesses atuais. Ela mobiliza tradição como tradição perigosa e, com isso, como potência libertadora em relação à unidimensionalidade e à segurança daqueles cujo ‘tempo sempre está pronto' (Jo 7.6). [...] A memória do sofrimento no sentido cristão não se esquiva na nebulosidade de arbitrariedade social e política, mas aguça a consciência social e política no interesse e sofrimento de outros. Ela evita a privatização e internacionalização do sofrimento e a nivelação de sua 
dimensão social. Nessa memória de sofrimento, história de sofrimento e história de opressão social não são simplesmente idênticas, mas também não concretamente separáveis (METZ, 1992, p. 95, 116).

Dessa maneira, a memória da romaria vai sendo edificada concretamente, por ação litúrgica, com os últimos da sociedade, com as vítimas. No Brasil, essas vítimas não são sujeitos abstratos. Elas são as pessoas pobres, negras, indígenas, mulheres, pessoas LGBT, meninos/as de rua, as pessoas das favelas, os sem-terras, os analfabetos e tantas outras. Pelos sofredores e pelas vítimas é reescrita e escrita continuamente a história, uma anti-história (J. B. Metz). Então a memória não é nenhum mero exercício de pensamento. Memória do sofrimento provoca mudança no sistema social. "Ela nos obriga a olhar para o theatrum mundi público não só pela perspectiva dos que conseguiram passar e chegar, mas também dos derrotados e das vítimas" (METZ, 1972, p. 401).

Também os mortos e os assassinados desempenham um importante papel na memória das vítimas. Por isso os agricultores, assassinados pelos latifundiários e nas romarias invocados como presentes, são tão importantes. "Uma pessoa vive quando é invocado o seu nome" (ASSMANN, 2000, p. 63). Pela memória os mortos não são só lembrados, mas estão entre nós. Diz-se aquilo que é necessário saber sobre os mortos, o que sofreram e com que sonharam. "Na ligação memorial com os mortos, uma comunidade se certifica de sua identidade" (ASSMANN, 2000, p. 63). Steffensky é ainda mais explícito: "Memória dos mortos cria terra natal. Vive-se diferente num lugar em que se conhece o nome dos mortos, em que se conhece as relações, também as de culpa e destruição. Terra natal é o lugar da memória dos êxitos e das perdas da vida." (STEFFENSKY, 1998, p. 88).

Ocupar-se com a memória conduz a uma problemática do Brasil ainda mais complicada. A memória não foi só tirada dos que sofrem, mas todo o povo do Brasil sofre de uma espécie de amnésia histórico-mitológica. Sob o provocativo título Brasilien - Land obne Gedächtnis? [Brasil - país sem memória?] foi publicado na Universidade de Hamburgo, em 2001, um livro que conduz a essa discussão:

Esse enorme Brasil econômico e geográfico não possui - diferentemente de países europeus, asiáticos, africanos ou também latino-americanos - nenhuma tradição coletiva, nenhuma tradição ilesa e, nesse sentido, também nenhum bem cultural comum, que a gente pudesse lembrar. Também faltam técnicas culturais que poderiam possibilitar algo assim como uma memória comum. [...] Pois os habitantes do Brasil preferiam viver o agora. Eles se permitiam ter saudade, o anelo difuso por uma distância temporal e espacial, mas sua 
uma análise descritiva e reflexiva sobre a função da romaria da terra

memória nacional, intermediada por datas e monumentos, era subdesenvolvida (BENNINGHOFF-LÜHL, 2001, p. 11).

Eventos como a romaria permitem que a memória brasileira aflore em segmentos, grupos, populações, especialmente as marginalizadas, vulneráveis e invisibilizadas, que sempre conservaram e fortaleceram sua memória como fonte de resistência (BENNINGHOFF-LÜHL, 2001).

\section{O estar a caminho e em movimento}

A Romaria da Terra é essencialmente uma celebração que acontece no processo, no estar a caminho, em movimento. É peregrinação no sentido etimológico da palavra. Ela é um exemplo claro para o fato que o processo é mais importante que, propriamente, a meta.

A felicidade procurada não se acha sem se colocar a caminho e, por vezes, só depois de uma viagem bastante cansativa. 'O caminho é a meta' reproduz uma antiga sabedoria dos escaladores de montanhas. A viagem é uma espécie de processo de amadurecimento, sem o qual não se chega à meta verdadeira. Para encontrar a verdade é preciso que a gente - assim o dizem muitos - 'se ponha a caminho' (TWORUSCHKA, 2002, p. 167).

O Sagrado se faz caminho, se torna ambulante, móvel, transitório. A romaria é uma procissão da procura por algo maior, o que ficou muito evidenciado na geografia da romaria de Curitiba: o centro do poder - palácio, prefeitura e catedral - como microcosmos da própria cidade, da capital, precisa ser abandonado na busca por outro lugar, um lugar de festa autêntica. Essa romaria é a expressão adequada da procura vivenciada por espaço de vida e do encontro simbólico de espaços de vida no cotidiano de seus participantes. No estar a caminho, o movimento dos pés significa a última forma de esperança em alguma coisa que falta para a vida. Ao mesmo tempo, o estar a caminho é a expressão condensada da essência ritual da Romaria da Terra: Se sai de casa e das localidades para ir até o local da romaria, se caminha pelo corredor central e outros corredores em meio às pessoas; se faz a caminhada, a procissão, no local da romaria; se retorna para casa depois da romaria (ADAM, 2018).

No caso da romaria, considerando a situação de vulnerabilidade social de muitos dos seus participantes, a caminhada de um lugar para outro, significa um elemento novo na peregrinação. Peregrinações são buscas simbólicas por algo novo, que seja dentro do próprio peregrino. Na romaria, a busca sim- 
bólica ganha contornos concretos e políticos. Ela expressa a busca do lugar que falta para morar, plantar, trabalhar, conviver, viver em paz. A Romaria é celebrada na fronteira entre lugar e não lugar, e ali, na fronteira, acontece o novo - uma experiência-flow no sentido de M. Csikszentmihalyi (2000) ou uma experiência de communitas no sentido de V. Turner (1978; 1989).

Movimentação do corpo e alterações de lugar permitem ganhar sempre novas perspectivas. Posições espaciais de quem percebe que só são acessíveis e realizáveis por movimentação, e percepção encontram-se entrelaçadas tão estreitamente, que perspectivação é o momento realmente eficaz de toda percepção (FAILING; HEIMBROCK, 1998, p. 45).

A Romaria da Terra conseguiu desenvolver esse comportamento humano tão essencial - a caminhada e a passagem - numa forma política, litúrgica celebrativa.

Desde tempos imemoriais os seres humanos já se encontram a caminho, aparentemente até já na fase anterior do seu surgimento propriamente dito. Nesse processo não se tratava de movimentos migratórios ativos, mas de desvios de rota condicionados pelo clima e pelos espaços de vida (TWORUSCHKA, 2002, p. 120).

\section{Conclusão}

A caminhada condensa diversas nuances essenciais da vida humana. Ela tem a ver com corporeidade e movimento e tem a ver com necessidade social e geográfica. Toda romaria é um pouco caminhada do nordeste para as fábricas de São Paulo e uma fuga da polícia e dos pistoleiros contratados pelos fazendeiros. Toda Romaria da Terra é uma romaria, um procissão ou peregrinação na busca pelo sagrado, pelo transcendente, mesmo quando o Divino se poe a caminho com o povo. Sua caminhada é procura de sentido e pão e é caminhada e peregrinação em busca da misericórdia divina. É um pouco de viagem, tradição e devoção religiosa, uma descoberta do outro e é também grito e protesto e um sonho de alternativas.

O elemento da caminhada tem raízes bíblicas, acolhe a tradição indígena da Busca da Terra Sem Males (MELIÀ, 1991), lembra a imigração forçada de escravos negros da África. Mas ela também é expressão simbólica de falta de espaço, de marginalidade, de desespero diante de espaço de vida, dignidade e esperança.

Enquanto paradoxalmente pessoas precisam colocar-se a caminho para sobreviver, outras acham-se em crise de sentido, vazias ou doentes, por que 
uma análise descritiva e reflexiva sobre a função da romaria da terra

lhes falta movimento. Uma das crises da modernidade é a renúncia ao caminhar. Os olhos substituíram os pés. Meios de transporte, controle remoto, virtualidade, tecnologias e satélites encurtam os trechos de caminhos e usurpam o sentido do caminho. Talvez por isso médicos receitam a seus pacientes o hábito de caminhar em vez de remédios (HILLMAN, 1993, p. 51-57). As academias de ginástica fazem o mesmo. M. Douglas e N. Elias já falavam de um atrofiamento do corpo e da movimentação no mundo secularizado (ELIAS, 1997; DOUGLAS, 1998). Uma vez que cada religião se entende, de uma ou outra maneira, como uma forma de eterna caminhada (TWORUSCHKA, 2002, p. 52, 55), pode-se dizer que na religião se concentra um reservatório de mobilidade humana. Dessa forma, a Romaria da Terra tem uma função humana muito importante quando coloca pessoas em movimento. Pela combinação de estar a caminho, celebração e protesto social ela é, como tal, profética e uma forma de pregação sobre algo precisa se movimentar novamente.

Estar a caminho como uma ação tem no contexto brasileiro significado tanto sociológico quanto teológico e litúrgico. Inicialmente estar a caminho significa processo. O símbolo do caminho tem para nós, latino-americanos, grande significado. Caminho é, a um só tempo, meta e método. Estar a caminho corresponde, por um lado, ao nosso destino de fuga da miséria e, por outro, se encontra vinculado com novos horizontes de esperança. O caminhar condensa denúncia profética e anúncio escatológico. Nenhum outro provérbio tem tão profundo significado para os processos de libertação na América Latina como o de Antonio Machado Caminante no hay camino. El camino se hace al andar (A. Machado).

O próximo passo seria então a dança (FAILING, 1998, p. 60-66). Depois da caminhada, os participantes da Romaria da Terra dançaram como expressão da festa dos pobres. A dança do samba, a melhor expressão litúrgica da nossa identidade como brasileiros, deve sinalizar que os peregrinos não se encontram só a caminho com os índios, negros, mulheres, crianças, católicos, pentecostais e membros do Candomblé, mas que todos eles sentem, cheiram e ouvem a proximidade de novos céus e nova terra. Como diz E. Cardenal: "Nós ainda não chegamos ao salão de festa, mas fomos convidados e já vemos as luzes e já ouvimos a música (CARDENAL apud MARTIN, 1973, p. 50)".

Peregrinação como a Romaria da Terra transformam vidas não por causa de sua grandiosidade litúrgica, número de participantes, impacto das performances, tempo de duração, nem mesmo por causa dos seu discurso político de protesto e denúncia, ou os textos de seus cantos os a escolha de 
determinados textos bíblicos. Romarias da Terra transfomam pessoas, grupos, movimentos e comunidades, porque de alguma maneira eles já estão envolvidos em processos de resgate de memórias subversivas e perigosas, como a memória de Cristo. Romarias transformam porque suas caminhadas são mais que exercício físico ou espiritual, são caminhadas simbólicas, carregadas de sentido teológico e político. Para que servem então as romarias? Elas emolduram, realçam, reavivam, reforçam, redirecionam a memória do seu povo caminhando para o passado, no presente e sonhando com a caminhada futura. Em tempos de intolerância e desrespeito as memórias das pessoas vulneráveis e das vítimas, que as romarias possam revitalizar e transformar igrejas, movimentos, grupos e pessoas.

\section{Referências}

ADAM, Júlio Cézar. Entre peregrinação, turismo e liminaridade: a busca por lugares. Horizonte, Belo Horizonte, v. 16, n. 49, p. 66-87, jan./abr. 2018.

ADAM, Júlio Cézar. Liturgia com os pés: estudo sobre a função social do culto cristão. São Leopoldo: Sinodal/EST, 2012.

ASSMANN, Jan. Das kulturelle Gedächtnis: Schrift, Erinnerung und politische Identität in frühen Hochkulturen. 3. ed. München: Beck, 2000. p. 20s.

BENNINGHOFF-LÜHL, Sibylle; LEIBING, Annette (Hrsg.). Brasilien - Land ohne Gedächtnis? Hamburg: Uni Hamburg, 2001.

CPT. A Luta pela Terra: a comissão pastoral da terra 20 anos depois. São Paulo : Paulus, 1997.

CPTnacional. Disponível em https://www.cptnacional.org.br/acoes/romarias/114-romarias -2018/4447-31-romaria-da-terra-do-parana-celebra-o-deus-que-acampou-entre-nos

CPT-Paraná. Caderno de Liturgia. Curitiba, 2000.

CPT-Paraná. Folhas de Cantos.Curitiba, 2000.

CSIKSZENTMIHALYI, Mihaly. Das flow-Erlebnis: Jenseits von Angst und Langeweile - in Tun aufgehen. 8. Ed., Stuttgart : Klett-Cotta, 2000.

DESCRIÇÃO de vídeos, 2000. (pesquisa de campo conduzida pelo autor e arquivo pessoal).

DOUGLAS, Mary. Ritual, Tabu und Körpersymbolik: sozialanthropologische Studien in Industriegesellschaft und Stammeskultur. Frankfurt: Fischer Verlag, 1998. 
uma análise descritiva e reflexiva sobre a função da romaria da terra

ELIAS, Norbert: Über den Prozeß der Zivilisation. Soziogenetische und psychogenetische Untersuchungen. Frankfurt/Main, 1997.

FAILING, Wolf-Eckart; HEIMBROCK, Hans-Günter. Gelebte Religion wahrnehmen: Lebenswelt, Alltagskultur, Religionspraxis. Stuttgart: Kohlhammer, 1998.

HILLMAN, James. Cidade e Alma. São Paulo: Studio Nobel, 1993.

MELIÀ, Bartolomeu. El Guarani: experiencia religiosa. Assunción: Ceaduc/Cepag, 1991.

METZ, Johann Baptist. Glaube in Geschichte und Gesellschaft. Studien zu einer praktischen Fundamentaltheologie. 5. Ed. Mainz: Mathias-Grünewald, 1992.

METZ, Johann Baptist. Zukunft aus dem Gedächtnis des Leidens: Eine gegenwärtige Gestalt der Verantwortung des Glaubens. Concilium, v. 8, n. 6/7, p. 399-407, Zürich/Mainz, 1972.

STÉDILE, João Pedro (Org.). A reforma agrária e a luta do MST. 2 Ed. Petrópolis: Vozes, 1997.

STEFFENSKY, Fulbert. Erinnerung braucht Rituale. Praktische Theologie, v. 33, n. 2, p. 86-93, 1998.

TIERRA, Pedro; CASALDÁligA, Pedro; NASCIMENTO, Milton. Missa dos Quilombos. Polygram, 1995.

TURNER, Victor. Das Ritual: Struktur und Anti-Struktur. Frankfurt/New York: Campus Verlag, 1989.

TURNER, Victor; TURNER, Edith. Image and Pilgrimage in Christian Culture. Nova York: Columbia University Press, 1978.

TWORUSCHKA, Udo. Heilige Wege: Die Reise zu Gott in den Religionen. Frankfurt am Main: Verlag Otto Lembeck, 2002.

WOORTMANN, Ellen Fensterseifer. Deutsch - Brasilianische Memoiren. In: BENNINGHOFF-LÜHL, Sibylle; LEIBING, Annette (Hrsg.). Brasilien - Land ohne Gedächtnis? Hamburg: Uni Hamburg, p. 193-207, 2001. 